\title{
Electronic Instrumentation for Sensing Humidity in Wide Range
}

\author{
Tsuyoshi Matsui, Hiromi Eguchi, Keiichiro Mori and Taisuke Irie \\ Biotron Institute, Kyushu University, Fukuoka 812, Japan
}

(Received January 6, 1979)

\begin{abstract}
For the humidity control in wide range, an instrumentation was developed for sensing the humidity with the use of electric capacitance. The probe used was Brady Array BR-101B (Thunder Scientific Corp.) in which the electric capacitance was changed by humidity and temperature. The capacitance was converted to voltage, and equation (4) was presented for calculating the humidity as a function of output voltage and temperature. In this system, it was made possible to measure the humidity in temperature range of $0^{\circ} \mathrm{C}$ to $40^{\circ} \mathrm{C}$ by obtaining digital and analog outputs of relative humidity, absolute humidity and saturation deficit. Thus, the humidity was measured in wide range, especially in lower temperatures with reliable characteristics, and the humidity control in lower temperatures became possible by means of using this system as a feedback sensor.
\end{abstract}

The air humidity has been controlled hitherto within the temperature range of about $10^{\circ} \mathrm{C}$ to $40^{\circ} \mathrm{C}$, and it has been difficult to control the humidity in temperature range lower than $10^{\circ} \mathrm{C}$ in phytotron and growth cabinet, because there are no sensors for detecting the humidity in lower temperatures. However, the analysis of plant responses to the humidity in lower temperatures is needed in environmental control of plant growth. For measuring water content, it can be assured that the electric capacitance is useful. ${ }^{1-5}$ ) The present paper reports the instrumentation for sensing humidity in wide range by means of electric capacitance for the use of humidity control and micro-climatic analysis of humidity.

\section{MATERIAL AND METHODS}

A probe of the hygrometer used is Brady Array BR-101B (Thunder Scientific Corp.) which is a precise array of crystals and interstitial spaces forming semiconducting bodies, and the electric capacitance and resistance of this probe are changed by absorption and separation of water molecule. The structual materials which employed in the probe are stainless steel, gold, precious metals and glass. $\left.{ }^{6}\right)$ In this study, the capacitance was used for sensing air humidity. In this probe, a reliable response of capacitance to water content was given by making input of alternating current of about $90-220 \mathrm{~Hz}$. So, in this experiment, input of alternating current to the probe was set at $202 \mathrm{~Hz}$. Figure 2 shows a block diagram of sensing and data processing system. The amplitude of the sine wave of output changed according to water content in ambient air, which was converted to voltage to be used for measuring air humidity.

For the calibration of the humidity sensing, the ventilated psychrometer (Ōta) was used, where the temperature was measured by the thermistor (Takara). 


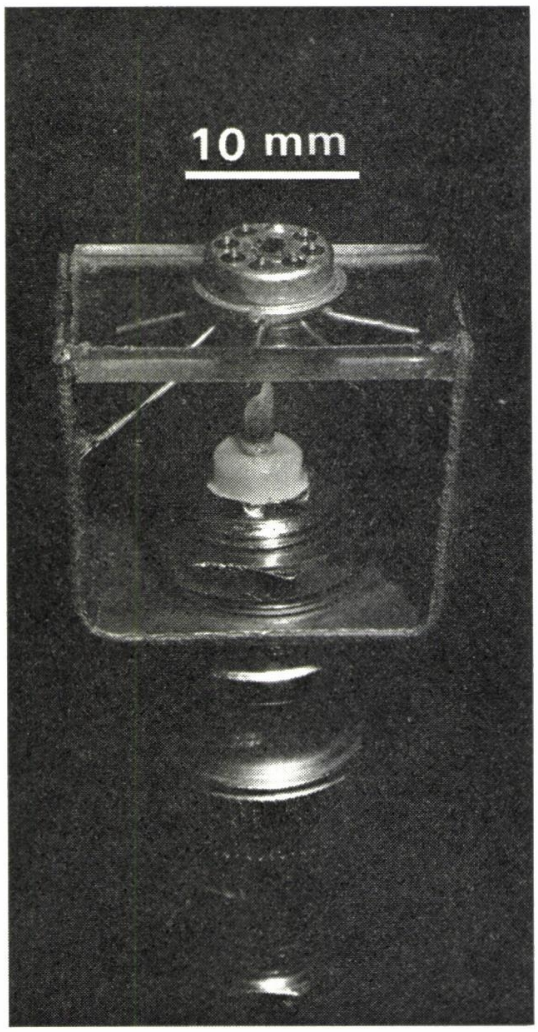

Fig. 1 Photograph of the probe, Brady Array BR-101B.

TEMPERATURE

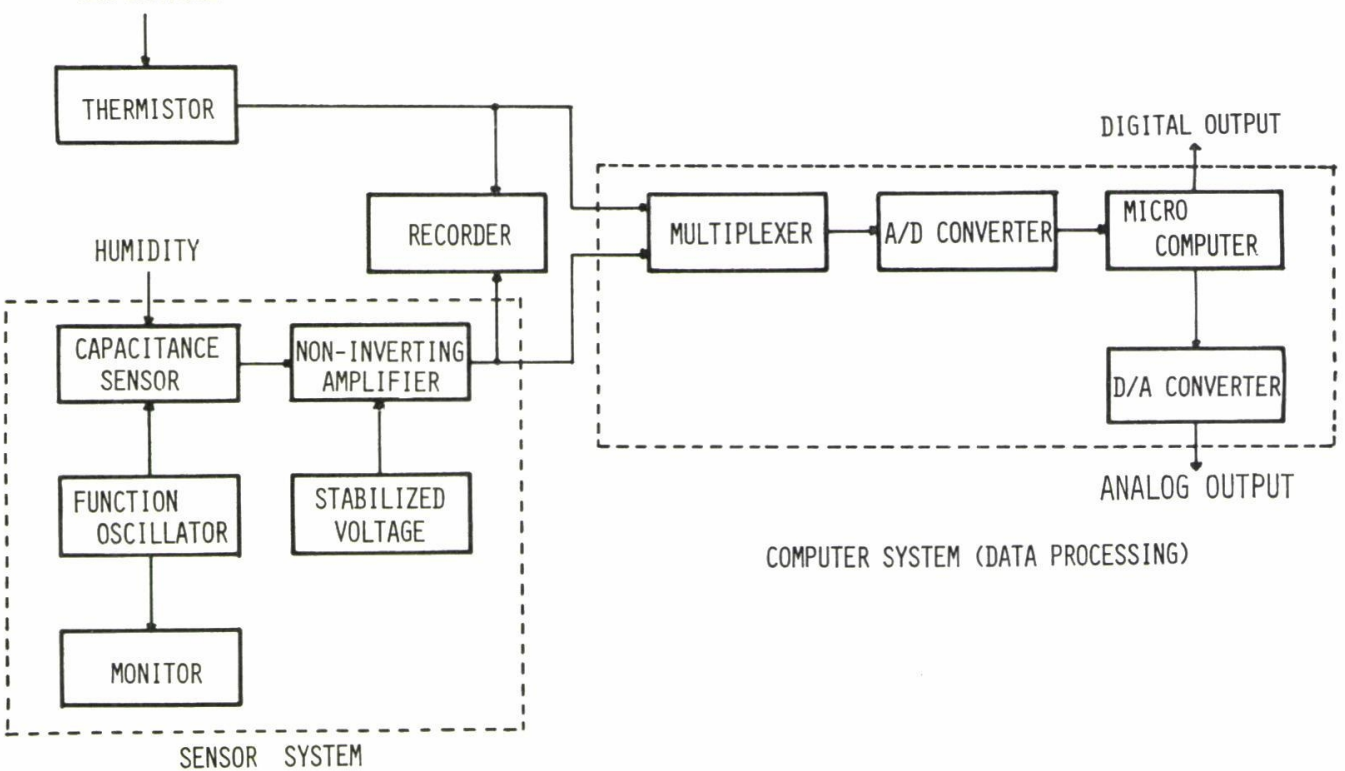

Fig. 2 Block diagram of sensing and data processing system. 


\section{RESULTS AND DISCUSSION}

Figure 3 shows distributions of relative humidity on output voltage in respective temperatures. The output voltage became higher in proportion to increase in relative humidity in a constant temperature. However, relations between relative humidity and output were different in respective temperatures. So, it was needed to make data processing for calculating the humidity from the functions of output and temperature. The patterns of relation between relative humidity $(R H, \%)$ and output voltage $(V$, volt $)$ were fitted to following equation in all temperatures,

$$
R H=a V^{b}
$$

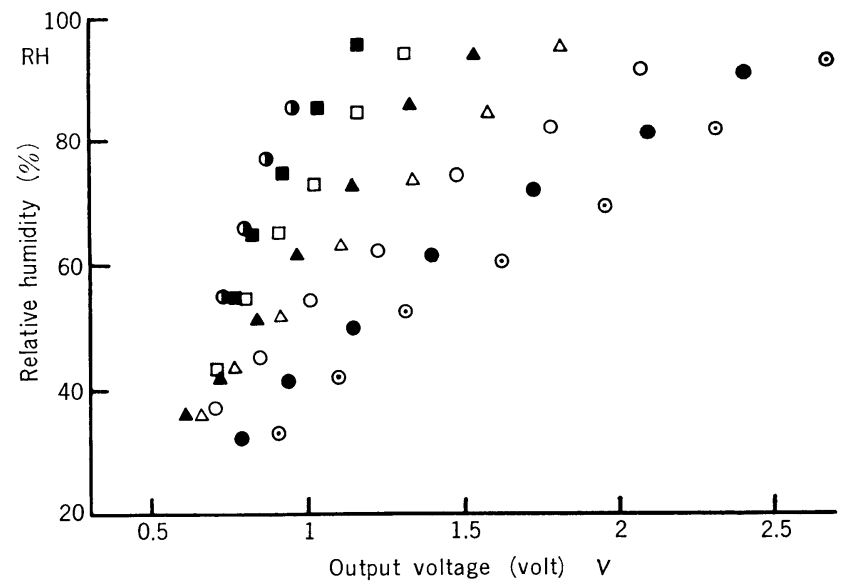

Fig. 3 Distributions of relative humidity on output voltage in respective temperatures. ๑, $5^{\circ} \mathrm{C} ; \boldsymbol{\square}, 10^{\circ} \mathrm{C} ; \square, 15^{\circ} \mathrm{C} ; \Delta, 20^{\circ} \mathrm{C} ; \triangle, 25^{\circ} \mathrm{C} ; \bigcirc, 30^{\circ} \mathrm{C} ; \bullet, 35^{\circ} \mathrm{C} ; \odot, 40^{\circ} \mathrm{C}$.

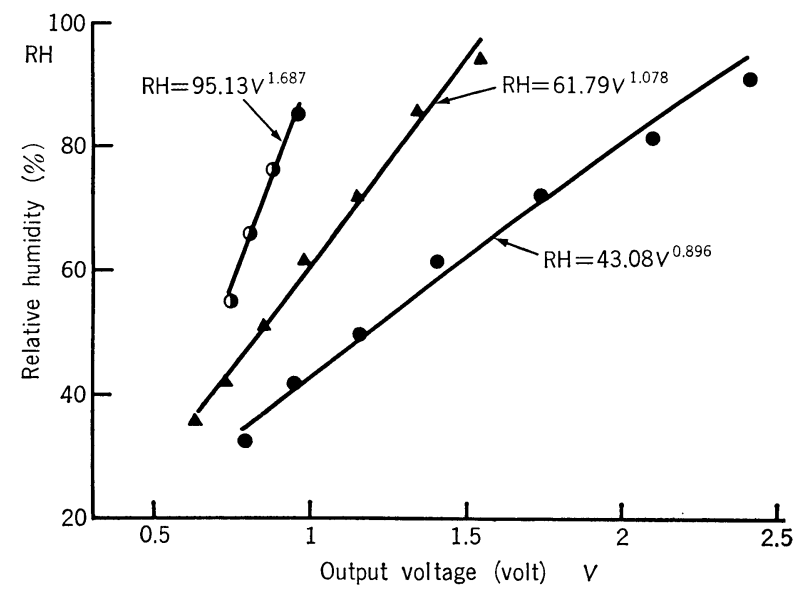

Fig. 4 Measured values of relative humidity and output voltage and the curves fitted to them. Measured values at $5^{\circ} \mathrm{C}(\mathbf{O}), 20^{\circ} \mathrm{C}(\boldsymbol{\Delta})$ and $35^{\circ} \mathrm{C}(\bullet)$, and curves fitted to measured values in respective temperatures. 
Figure 4 shows measured values of relative humidity and output voltage and curves fitted to them at 5,20 and $35^{\circ} \mathrm{C}$, respectively. In order to examine the degree of closeness of Eq. (1) to the measured $R H$ and $V$, the Eq. (1) was transformed to following equation,

$$
\log _{10} R H=b \log _{10} V+\log _{10} a
$$

By using Eq. (2), correlation between humidity and output voltage was analized. Table 1 shows correlation coefficients of $\log _{10} R H$ on $\log _{10} V$ in respective temperatures. The correlation coefficients were higher than 0.99 and significant at $0.1 \%$ level in all temperatures. This result indicates that the relative humidity was able to be given by the function of the output voltage within the range from $5^{\circ} \mathrm{C}$ to $40^{\circ} \mathrm{C}$. The coefficient $(a)$ and the exponent $(b)$ of Eq. (1) were represented, respectively, by the function of temperature $\left(T,{ }^{\circ} \mathrm{C}\right)$,

Table 1 Correlation coefficients of $\log _{10} R H$ on $\log _{10} V$ in respective temperatures.

\begin{tabular}{cc}
\hline $\begin{array}{c}\text { Temperature } \\
\left({ }^{\circ} \mathrm{C}\right)\end{array}$ & $\begin{array}{c}\text { Correlation } \\
\text { coefficient }\end{array}$ \\
\hline 5 & $0.994 * * *$ \\
10 & $0.987 * * *$ \\
15 & $0.989 * * *$ \\
20 & $0.997 * * *$ \\
25 & $0.998 * * *$ \\
30 & $0.994 * * *$ \\
35 & $0.993 * * *$ \\
40 & $0.995 * * *$ \\
\hline
\end{tabular}

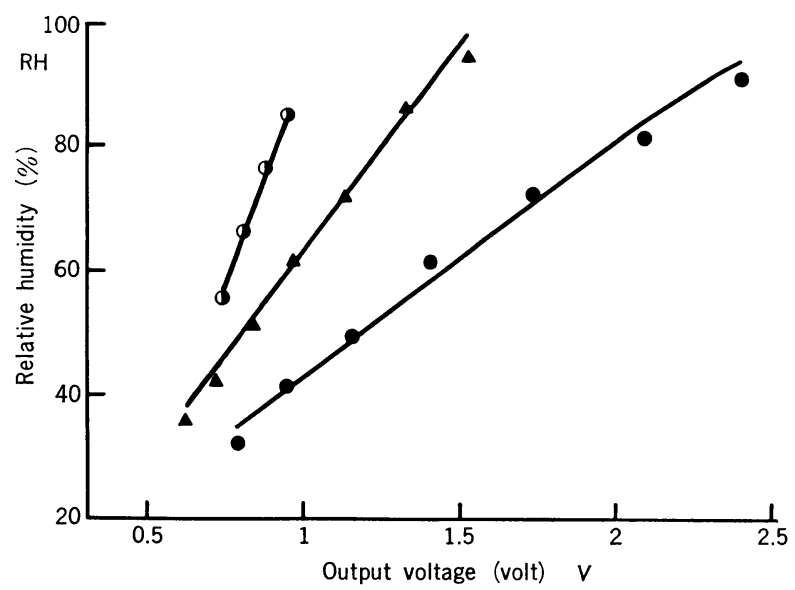

Fig. 5 Examples of the curves calculated from Eq. (4) and measured values of relative humidity and output voltage.

Measured values at $5^{\circ} \mathrm{C}(\boldsymbol{\oplus}), 20^{\circ} \mathrm{C}(\Delta)$ and $35^{\circ} \mathrm{C}(\bullet)$, and curves fitted to measured values in respective temperatures. 


$$
\left.\begin{array}{l}
a=1.05 \times 10^{2}-2.67 T+2.50 \times 10^{-2} T^{2} \\
b=1.95-6.50 \times 10^{-2} T+9.80 \times 10^{-4} T^{2}
\end{array}\right\}
$$

where $5 \leqq T \leqq 40$.

From Eqs. (1) and (3), the relative humidity $(R H)$ was given by the function of the output voltage $(V)$ and the temperature $(T)$,

$$
\left.R H=\left(1.05 \times 10^{2}-2.67 T+2.50 \times 10^{-2} T^{2}\right) V^{\left(1.95-6.50 \times 10^{-2} T+9.80 \times 10^{-4} T^{2}\right.}\right)
$$

where $30<R H<100, \quad 0.5<V<2.7$.

Figure 5 shows examples of the curves calculated from Eq. (4) and measured values of relative humidity and output voltage at 5,20 and $35^{\circ} \mathrm{C}$, respectively. From the fact that the measured values closed to the calculated curves, it was estimated that Eq. (4) could be useful for calculating the relative humidity from output voltage and temperature. Figure 6 shows a flow-chart of the processing in micro-computer. The $a_{0}, a_{1}, a_{2}$, $b_{0}, b_{1}$ and $b_{2}$ were the fixed numbers of the probe's own, respectively. The saturated vapor pressure was calculated from the Goff-Gratch's equation, ${ }^{7)}$ and digital and analog signals of relative humidity $(R H)$, absolute humidity $(A H)$ and saturation deficit $\left(S_{D}\right)$ were obtained respectively.

The response time of this system was one second or less, and its accuracy was less than $\pm 4 \%$ containing the small hysteresis. Thus, it was made possible to improve the method heretofore for sensing humidity in its range and response characteristics. For the reason of the limited capacity of the growth cabinet used in this experiment, the processing was per-

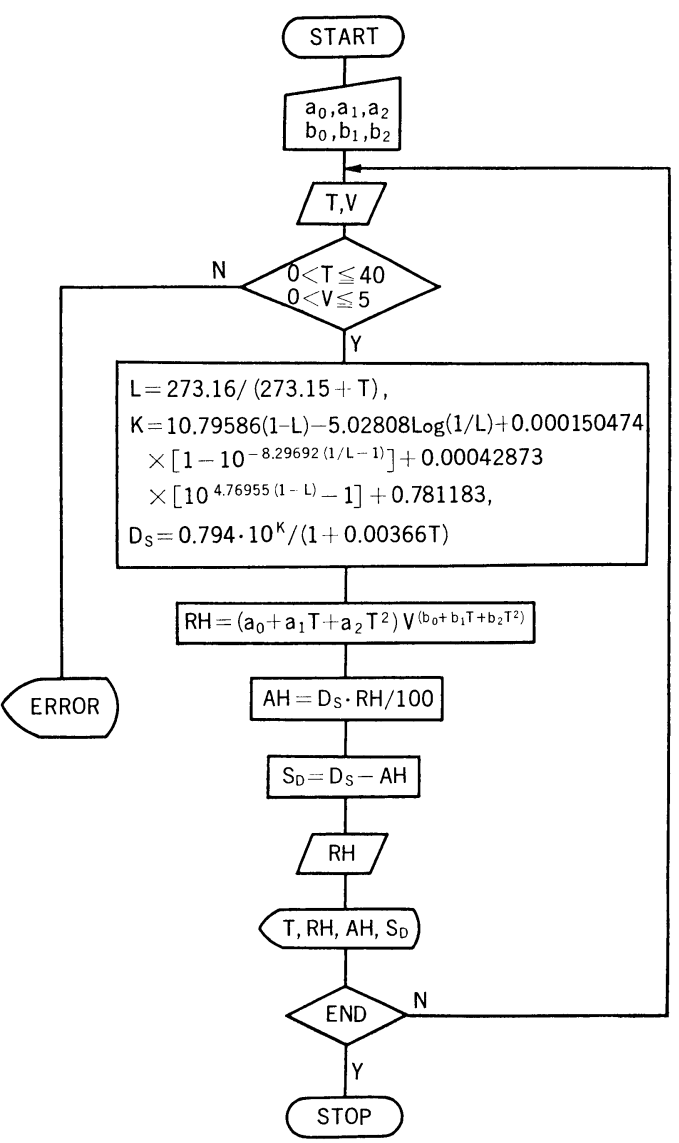

Fig. 6 Flow-chart of data processing. $D_{s}$, saturated vapor content. formed in temperature range of $5^{\circ} \mathrm{C}$ to $40^{\circ} \mathrm{C}$. However, from the physical principle of the probe, this system could be considered to be useful for measuring the humidity in temperature range of $0^{\circ} \mathrm{C}$ to $40^{\circ} \mathrm{C}$ and made it possible to be used as the feedback sensor for the humidity control in lower temperatures. 


\section{REFERENCES}

1) Cutting, C. L., A. C. JASON, and J. L. Wood. 1955. A capacitance-resistance hygrometer. J. Sci. Instrum. 32: 425-431.

2) UNDERWOOD, C. R., and R. C. HousLIP. 1955. The behaviour of humidity-sensitive capacitors at room temperatures. J. Sci. Instrum. 32: 432-436.

3) Mattews, J. 1963. The design of an electrical capacitance-type moisture meter for agricultural use. J. Agric. Eng. Res. 8: 17-30.

4) Thomas, A. M. 1966. In situ measurement of moisture in soil and similar substances by 'fringe' capacitance. J. Sci. Instrum. 43: 21-27.

5) Hashimoto, Y., B. IChIJo, K. NonaKa, K. Omasa, and S. Funada. 1974. Electronic instrumentation of water content in plants. Environ. Control in Biol. 12: 69-72.

6) BeNNEwitz, P.F. 1973. The Brady Array-a new bulk-effect humidity sensor. In "Automobile Engineering Meeting, Detroit, Mich." 703571:1-6, Society of Automotive Engineers, Inc., New York.

7) GofF, J. A., and S. Gratch. 1946. Low-pressure properties of water from -160 to +212F. Trans. Am. Soc., Heat and Vent. Eng. 52: 95.

\section{$<$ 和文抄録 $>$}

\section{広域湿度制御のための電子的計装 \\ 松井 健・江口弘美・森 晸一郎・入江泰 輔 \\ 九州大学生物環境調節センター}

静電容量による水分量計測の原理を用いて，空気湿度の計測と制御のための装置の開発を試みた．湿 度計測用 probe として Brady Array BR-101B (Thunder Scientific Corp.) を用い，水分吸着あるいは 放出によっておこる静電容量の変化を電圧として出力し, 計測に用いた。この出力（電圧）は相刘湿度 の変化に対応したが，その特性は温度に影響された。 そこで温度に対するこの感度特性の変化をりフト ウェアで処理する方法を採った．各温度条件における相対湿度（RH，\%）とセンサーシステムからの 出力 $(V$, volt $)$ の関係は $R H=a V^{b}$ で示され, また $a, b$ は温度 $\left(T,{ }^{\circ} \mathrm{C}\right)$ の関数で与えられた．演算 装置としてマイクロコンピュータを用い, 相対湿度, 絶対湿度, 飽差を算出し, デジタル表示をすると 同時にアナログで出力した．実測範囲を環境制御装置の能力から $5^{\circ} \mathrm{C} \leqq T \leqq 40^{\circ} \mathrm{C}$ に限定せざるを得な かったが，本センサーの原理から考えれば，さらに広い温度域での湿度測定が可能と考えられ，低温域 での湿度制御用フィードバックセンサーとして使用しうることがわかった。 